\title{
Analysis of the Influence of Transient Process During the Shunt Reactors Commutation on Insulation of Substation "Zarya" Auxiliaries
}

\author{
Evgenia U. Sizganova*, Roman A. Petukhov, \\ Nikita V. Sizganov and Daria U. Nikotina \\ Siberian Federal University \\ 79 Svobodny, Krasnoyarsk, 660041, Russia
}

Received 09.10.2015, received in revised form 14.12.2015, accepted 29.01.2015

The article considers the modeling and analysis of transient processes in a system of substation Zarya500 $\mathrm{kV}$ with different external conditions during commutation shunt reactor ROMBS-60000/500. Revealed that the high-frequency overvoltageduring switching shunt reactor of $500 \mathrm{kV}$, can be dangerous for air insulation transformers TSZ-630/15.

Keywords: substation, shunt reactors, switching surges, auxiliary transformers, surge arresters, autotransformers, the current cutoff, replicate samples.

Citation: Sizganova E.U., Petukhov R.A., Sizganov N.V., Nikotina D.U., Analysis of the influence of transient process during the shunt reactors commutation on insulation of substation "Zarya" auxiliaries, J. Sib. Fed. Univ. Eng. technol., 2016, 9(2), 225-236, DOI: 10.17516/1999-494X-2016-9-2-225-236.

(C) Siberian Federal University. All rights reserved

* Corresponding author E-mail address: seu_eset@mail.ru 


\title{
Анализ влияния переходных процессов \\ при коммутации шунтирующих реакторов \\ на изоляцию оборудования собственных нужд \\ подстанции «Заря»
}

\author{
Е.Ю. Сизганова, Р. А. Петухов, \\ Н.В. Сизганов, Д.Ю. Никотина \\ Сибирский федеральный университет \\ Россия, 660041, Красноярск, пр. Свободный, 79
}

\begin{abstract}
Даны основные характеристики исследуемого объекта. Разработана схема моделирования и определены эквивалентные параметры ПС «Заря» 500 кВ. Исследованы перенапряжения при отключении шунтирующего реактора, вызванные срезом токов в выключателе, а также повторным пробоем межконтактных промежутков. Оиенено влияние отходящих линий на перенапряжения при отключении шунтирующего реактора, вызванные срезом токов в выключателе.
\end{abstract}

Ключевые слова: подстанция, шунтируюший реактор, коммутационные перенапряжения, трансформатор собственных нужд, разрядники, автотрансформаторы, срез тока, повторный пробой.

Shunt reactor (SR) is the source of reactive power for electric networks $500 \mathrm{kV}$, which is able to operate a number of functions: decrease of power loss; maintenance of reactive power under acceptable bounds; increase of transmission line throughput according to conditions' stability; maintenance of voltage levels under acceptable bounds, described in Technical operation rules for power plants and networks of the Russian Federation

Nowadays more than 270 shunt reactors for electric networks $500 \mathrm{kV}$ are set at substations «FGC FEES» JSC. Frequent commutations of electric SR on average, about 100 in year and even 1000 at some objects [1], cause a failure of circuit breaker, that commutate reactors. High arc suppression effect in breakers during disconnection of SR may cause current section with instantaneous value 25-40 A (according to some data - 70 A). High voltage recovery of breakers' switch contacts after current section and small contact gaps in the moment of arc interruption may cause re-ignition of the arc, that in total may become a reason for high frequency overvoltages, affection isolation of both SR and the substation. Sometimes high frequency overvoltages may transform at low voltage switchgear by capacitive couplings of transformer and cause considerable high frequency oscillations [2] in it.

Since 2007 five technical work violations involving auxiliary transformers TSZ-630/15 occurred at substation Zarya $500 \mathrm{kV}$. All of them were preceded by commutation of shunt reactor at open switchgear $500 \mathrm{kV}$. In order to reveal the reasons of the AT damage it is necessary to examine transient oscillation caused by SR commutations and analyze the effect they have on the insulation of auxiliary equipment. It is impossible to investigate high frequency overvoltage on substation elements caused by SR R-532 commutations at a real object or at a physical model. That's why it is essential to create an simulation model which would be adequate to the real object (Fig. 1) 


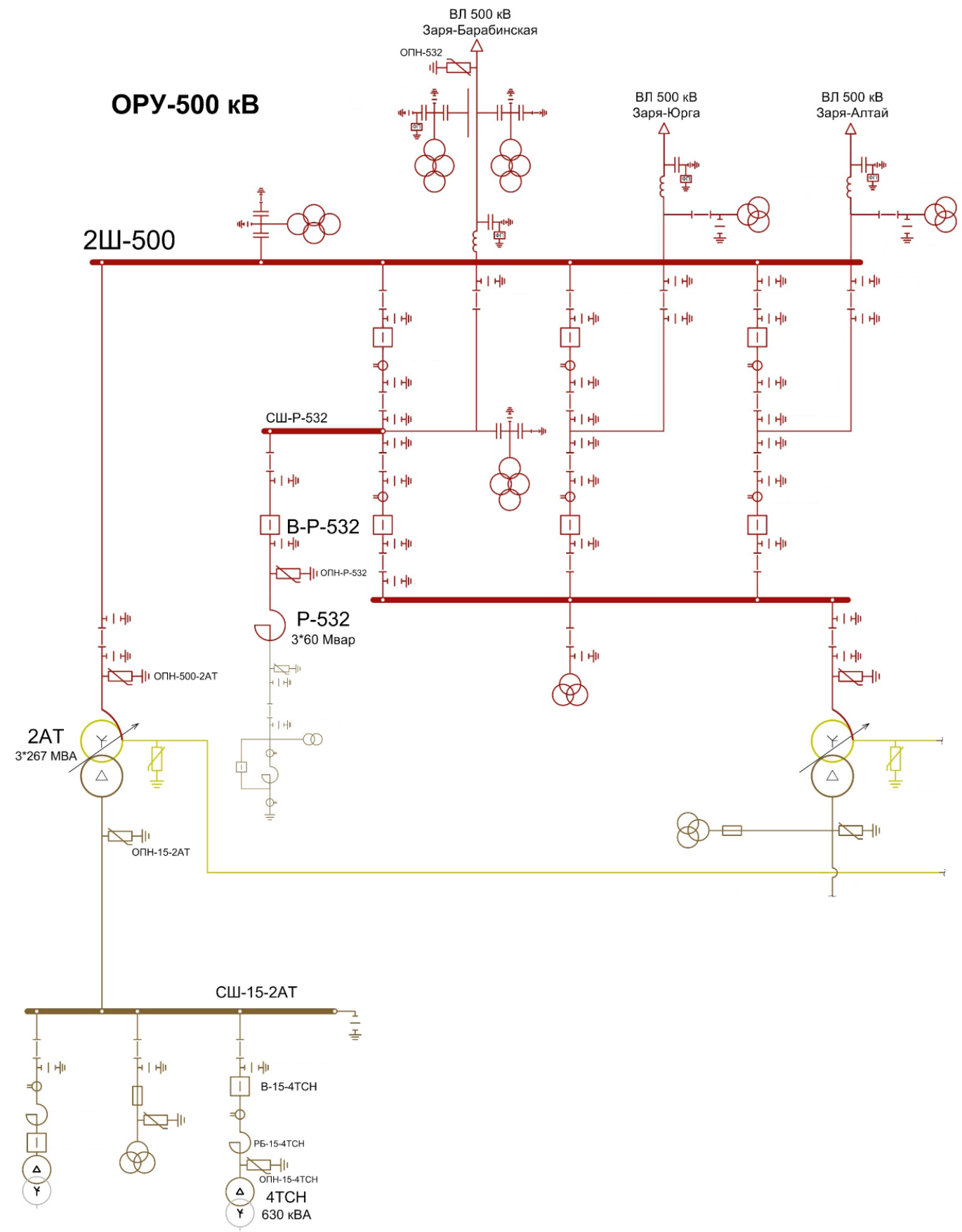

Fig 1. The scheme of electrical coupling of the substation Zarya $500 \mathrm{kV}$ 's investigated sector

Major characteristics of the object of study. The substation $500 \mathrm{kV}$ Zarya with fixed power of 1600 MVA was launched in 1972. Electric power supply of Novosibirsk city and some administrative districts on the east if Novosibirsk region. Beside this fact, this substantion determines the functioning of interconnection between Novosibirsk and Omsk's power grids within Siberian UES through the poew transmission line $500 \mathrm{kV}$ Zarya - Barabinskaya - Tavricheskaya. 
Open switchgears (OS) $500 \mathrm{kV}$ is constructed according to a scheme of doublebus substation with two breakers (Fig. 1). OS $220 \mathrm{kV}$ is a double busbar with bypass. Shunt reactors $500 \mathrm{kV}$ are connected to the additional bus between breakers Overhead power line (OVL) - 532 Zarya Barabinskaya. Auxiliary power supply occurs at $\mathrm{Uном}=15,75$ from low voltage winding of autotransformer.

Autotransformers АОДЦТН-267000/500/220-У1, auxiliary transformers ТС3-630/15 and BEZaTSE 772/10, shunt rectors РОМБС-60000/500, current limiting reactors CL1-0,16/6000/125, breakers HPL 550 В2, ВМП-35П, disconnectors РГЖ-1-500 II/3150, surge arrestors ABВ EXLIM P-396-GH-550 and OПН-15/15,7-10.

Development of modeling scheme and definition of equivalent parameters of substation Zarya $500 \mathrm{kV}$. Modeling is realized in environment MATLAB [7]. Equivalent circuit of OS-500 kV is developed according to the plan OS and incision into cells, described in the [3]. While high frequency of processes, input impedance of autotransformers, measuring transformers and devices were replaced with input capacitances. For easiness of devices were installed in nodal points. Beside this the ultimate length of linking wires between substational nodal points and devices were considered. Capacitances and inductances of autotransformer 2AT, defining the passage of electromagnetic wave through it, were computed on the basis of autotransformers' passport details.

Equivalent inductive resistance of network $500 \mathrm{kV}$, adjoining substation Zarya $500 \mathrm{kV}$, was calculated relying on rated current single-phase and three-phase short circuit on $500 \mathrm{kV}$ buses of above mentioned substations. For modeling were established the following equivalent inductances of direct and zero sequences of the systems adjoining the open switchgear $-500 \mathrm{kV}$ : the inductances of the Barabinskaya substation $L_{532}^{1}=0,264 \mathrm{H}, L_{532}^{0}=0,309 \mathrm{H}$; the inductances of the Yurga substation $L_{531}^{1}=0,162 \mathrm{H}, L_{531}^{0}=0,217 \mathrm{H}$; the inductances of the Altay substation $L_{533}^{1}=0,096 \mathrm{H}, L_{533}^{0}=0,107 \mathrm{H}$; the inductances of the Zarya substation from the $220 \mathrm{kV}$ windings of autotransformers $1 \mathrm{AT}$ and $2 \mathrm{AT}$ $L_{220}^{1}=0,459 \mathrm{H}, L_{220}^{0}=0,132 \mathrm{H}$.

Bus parameters are defined considering phases geometry, midspan sags, conductor cross-section and resistivity of wires.

For modeling parameters of surge arrester (SA) EXLIM P-396-GH-550 the coefficients $\alpha_{i}$ and $K_{i}$ were calculated on the current-voltage characteristic (CVC) presented in passport details of SA and using the following formulas:

$$
\alpha_{i}=\frac{\left(\frac{\mathrm{I}_{\mathrm{i}}+1}{\mathrm{I}_{\mathrm{i}}}\right)}{\left(\frac{\mathrm{U}_{\mathrm{i}}+1}{\mathrm{U}_{\mathrm{i}}}\right)}, \quad \mathrm{K}_{\mathrm{i}}=\frac{\left(\frac{\mathrm{U}_{\mathrm{i}}}{\mathrm{U}_{\text {баз }}}\right)}{\left(\frac{\mathrm{I}_{\mathrm{i}}}{\mathrm{I}_{\text {баз }}}\right)^{1 / \alpha_{\mathrm{i}}}}
$$

where $I_{i}$ is the current of $i$ th point of $\mathrm{CVC}$ of the modeling SA; $I_{\text {бas }}$ is the base current of the modeling $\mathrm{SA} ; U_{i}$ is the voltage of $i$ th point of $\mathrm{CVC}$ of the modeling SA; $U_{\tilde{\sigma} \boldsymbol{}}$ is the base voltage of the modeling SA.

For the current section modelling there was constructed a combined model, consisting of: the element Simulink - «ThreePhaseBreaker» and three "ideal" single - phase breakers, connected in series. Such scheme allowed to switch off currents both in the moment of zero value and to cutoff the current at particular moments. 
Models of transformers 2AT and TCN were created using the element Simulink - «ThreePhase Transformer (TwoWindings)» and capacitance between high and low voltage winding and ground, and also the capacitance between windings.

Overvoltage during the reactor R-532 disconnection, caused by current cutoff in a breaker. Processes of SR disconnection caused by only the current cutoff in a breaker within asimplified scheme, regardless of the outcoming powerlines and without replicate sample of contact gaps, were considered beforehand.

To compute the multiplicity of overltage on the current cutoff in different points of the scheme, with or without SA, it is essential to repeatedly implement scheme simulation, changing the parameter of current cutoff and the following registration of the maximum amplitude of overvoltage figures. As the higher current cutoff in a breaker is at low-probability, calculations were made for the current range of 0-100 A with step of $10 \mathrm{~A}$. Numerical repletion of the scheme simulation was realized using a program code, entered into the command window of Matlab.

The series of experiments revealed that the ratio of the overvoltage multiplicity and phase peak voltage, considering work of surge arrestor, doesn't exceed 1,8 for real value of the current cutoff Icp.

Overvoltage during the SR disconnection, caused but the current cutoff in a breaker, affect the insulation only on the part of shunt reactor (Fig. 2). Overvoltages almost does not occur on the part of the OS. During the transient with shunt reactor R-532 commutation, high frequency oscillations occur on the part of the reactor with the main frequency of $2,1 \mathrm{kHz}$ (Fig. 3) mainly dependent on the SR inductivity and capacity of winding insulation

Oscillations, occurring while current cutoff in a breaker, have comparatively low value on the part of the high voltage winding of $2 \mathrm{AT}$ (Fig. 4,a). If transferred on the winding $15 \mathrm{kV}$ of $2 \mathrm{AT}$, they increase significantly (Fig. 4,b), at the same time the high frequency oscillations considerably excitate at the 4TSN (Fig. 4,c) with overvoltage multiplicity of $2.34 U_{\phi \text { макс. }}$.
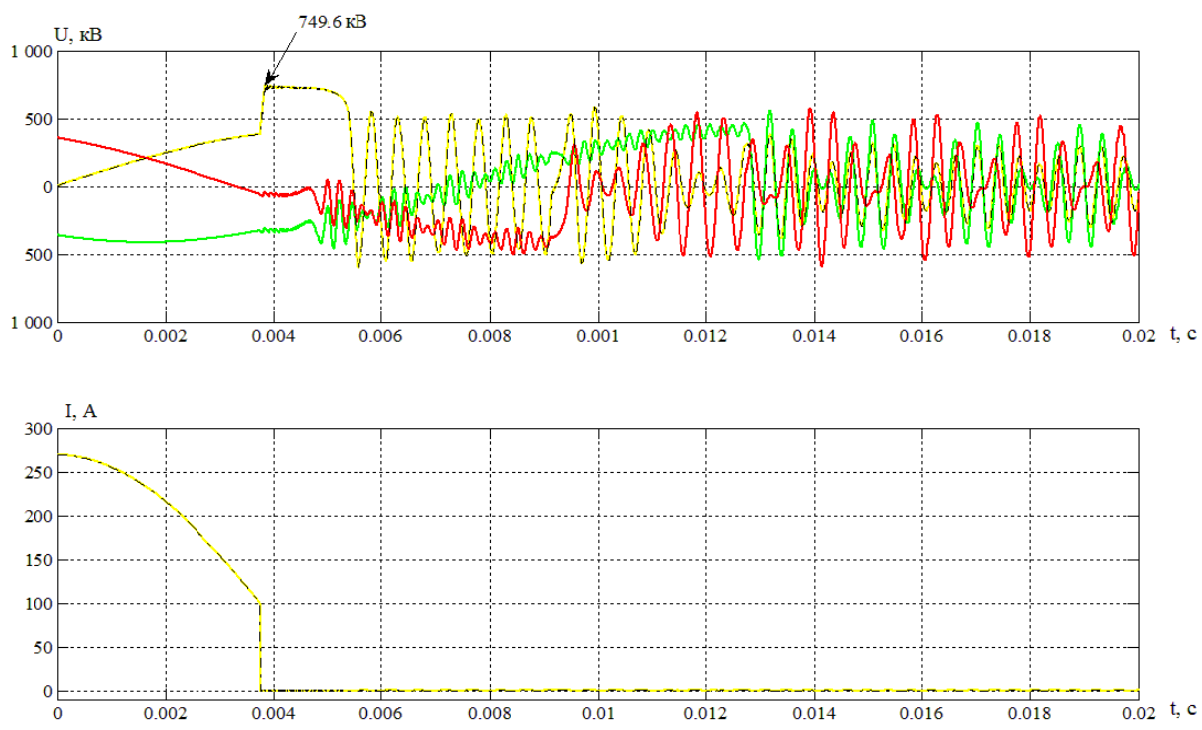

Fig. 2. Voltage on the part of the shunt reactor and the current flowing through the breaker while cutoff the current amplitude $100 \mathrm{~A}$ 

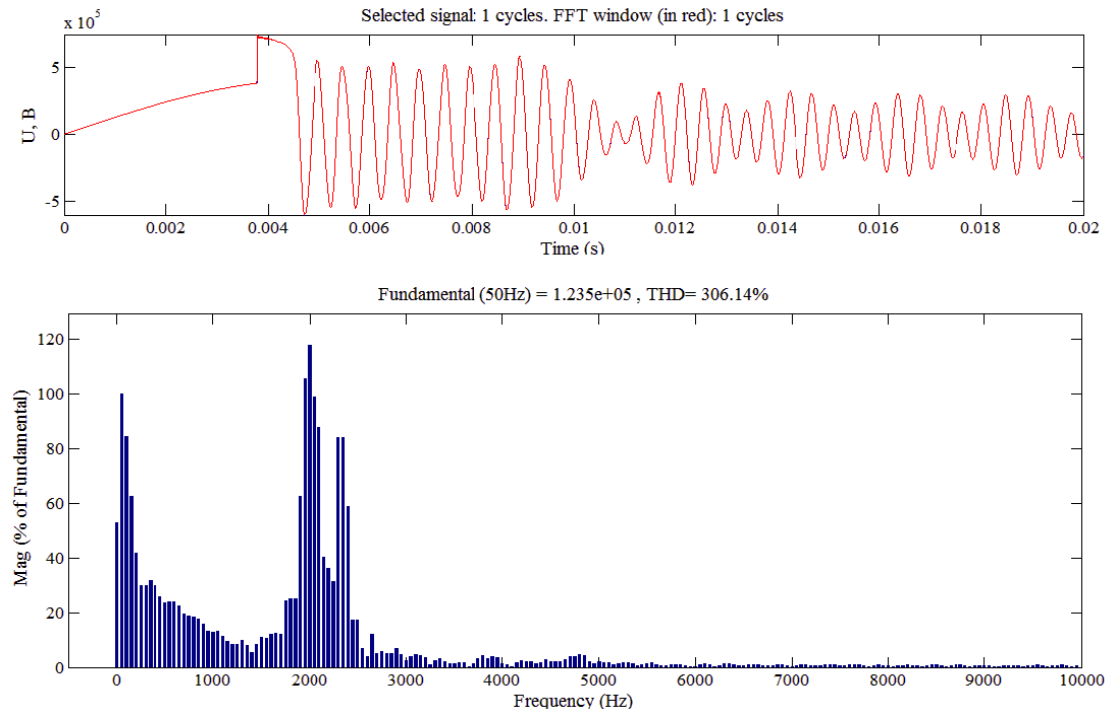

Fig. 3. Amplitude-frequency characteristic of the phase A voltage at the reactor R-532

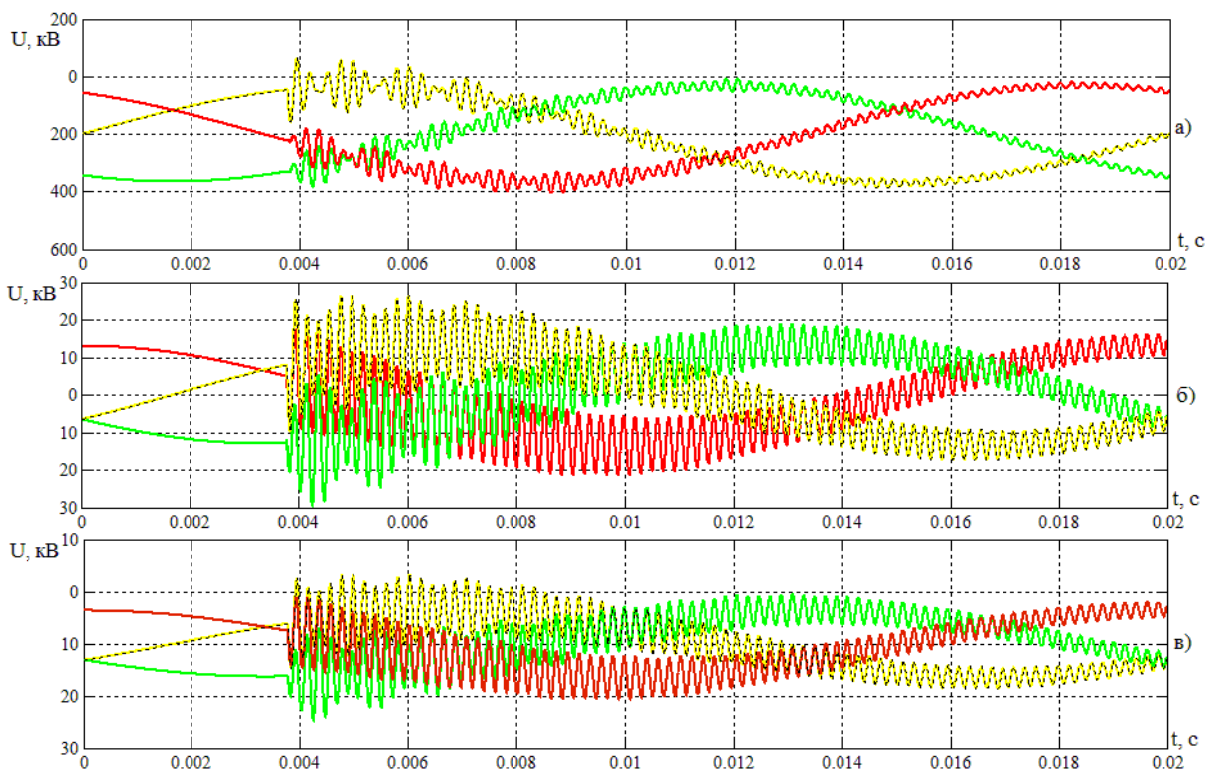

Fig.4. Oscillations caused by current cutoff in a breaker during the SR disconnection: a0 on the part of $500 \mathrm{kV}$ of 2AT; b) on the part of $15 \mathrm{kV} \mathrm{AT;} \mathrm{c)} \mathrm{at} \mathrm{4TSN} \mathrm{transformer}$

The process of modeling revealed that high frequency overvoltages transform down to LowVoltageSwitchgear and 4TSN transformer, mainly by capacitive couplings of the autotransformer 2AT and cause high frequency oscillations with the frequency of $83,4 \mathrm{kHz}$ in them (Fig. 5). Second breakdown between contacts of a breaker cause a significant increase of oscillations. Therefore, the main purpose of the later research was investigation of transient, caused by current cutoff in breaker with repeated arc ignition between its contacts. 

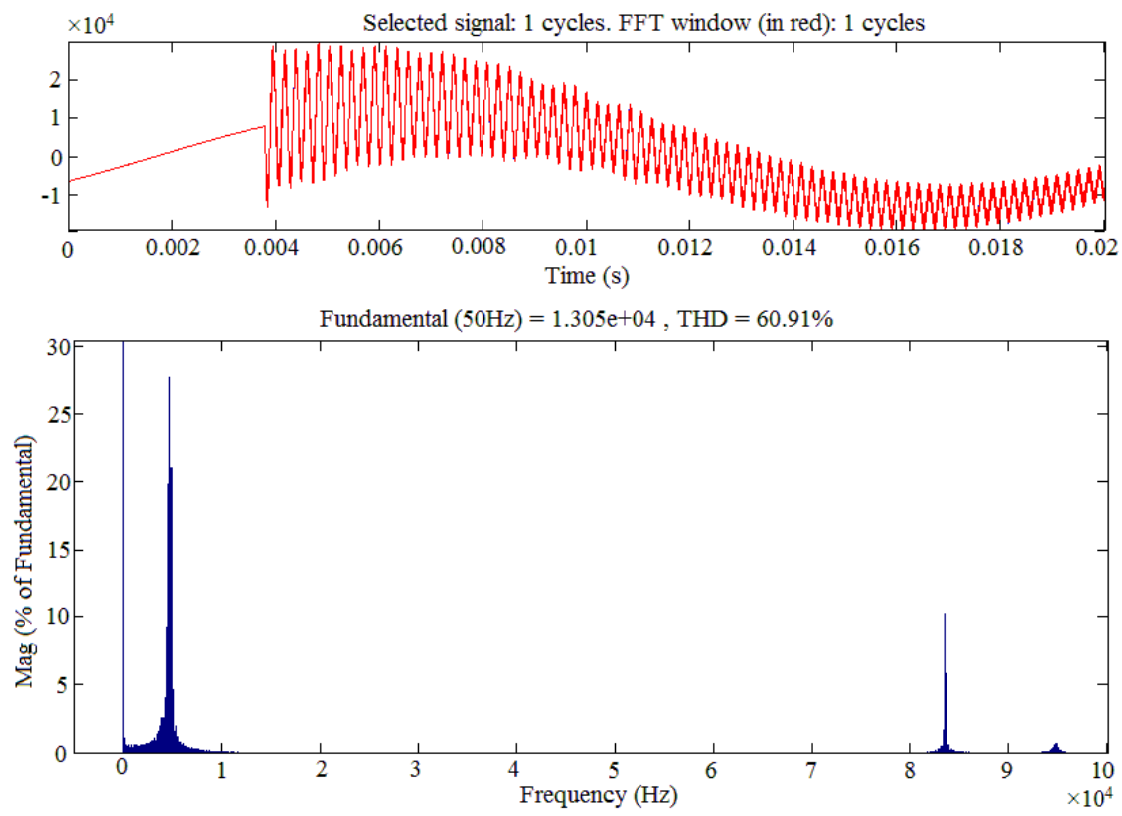

Fig. 5. Amplitude-frequency characteristic of oscillation of the phase A of the 4TSN transformer

Outgoing lines' influence on overvoltage withing R-532 reactor disconnection, caused by current cutoff in a breaker. Outgoing powerlines have a big impact on processes occurring at substation. There are $3500 \mathrm{kV}$ lines outgoing from substation Zarya: Zarya - Barabinskaya line, Zaraya- Yurga line and Zarya - Altay line, in addition, it is necessary to take into consideration the influence of parallel working 1 AT autotransformer with its busbar. Considering all the outgoing lines and $1 \mathrm{AT}$ there occurs almost no overvoltage caused by current cutoff in a breaker on the part of OS $500 \mathrm{kV}$ (Fig. 6,a). However, even a slight voltage drop at a phase A of 2 AT autotransformer cause an excitation of high frequency oscillation at the 4TSN transformer after transformation down to low voltage winding (Fig. 6,b and 6,c).

Thus, it is necessary to regard a scheme with a minimum adjoint lines to get higest possible impact on the transformer 4TSN while reactor R-532 disconnection.

Modelling of processes with disconnected outgoing lines Zarya - Barabinskaya and Zarya Altay revealed that surge multiplicity on 4TSN transformer, caused by current cutoff in a breaker, rather increase (Fig. 7) but don't exceed 2.0 Uф макс. This increases down to the rise of high frequency component of the voltage $83.4 \mathrm{kHz}$ (Fig. 8)

Thus, considering the impact on the transformer 4TSN, the least appropriate regime for reactor $\mathrm{R}-532$ disconnection is the regime when the substation functions with the outgoing line Zarya - Yurga working only.

Overvoltage during the reactor R-532 disconnection, caused by replicate sample of contact gaps. As the calculations revealed, transient recovery voltage (TRV) begins to increase rapidly on the contacts as arc extincts during the current cutoff in a breaker. On this occasion the replicate samples of contact gaps may occur. In order not ot get lower results the moments of replicate samples corresponded to the maximum of TRV amplitude modulus. 


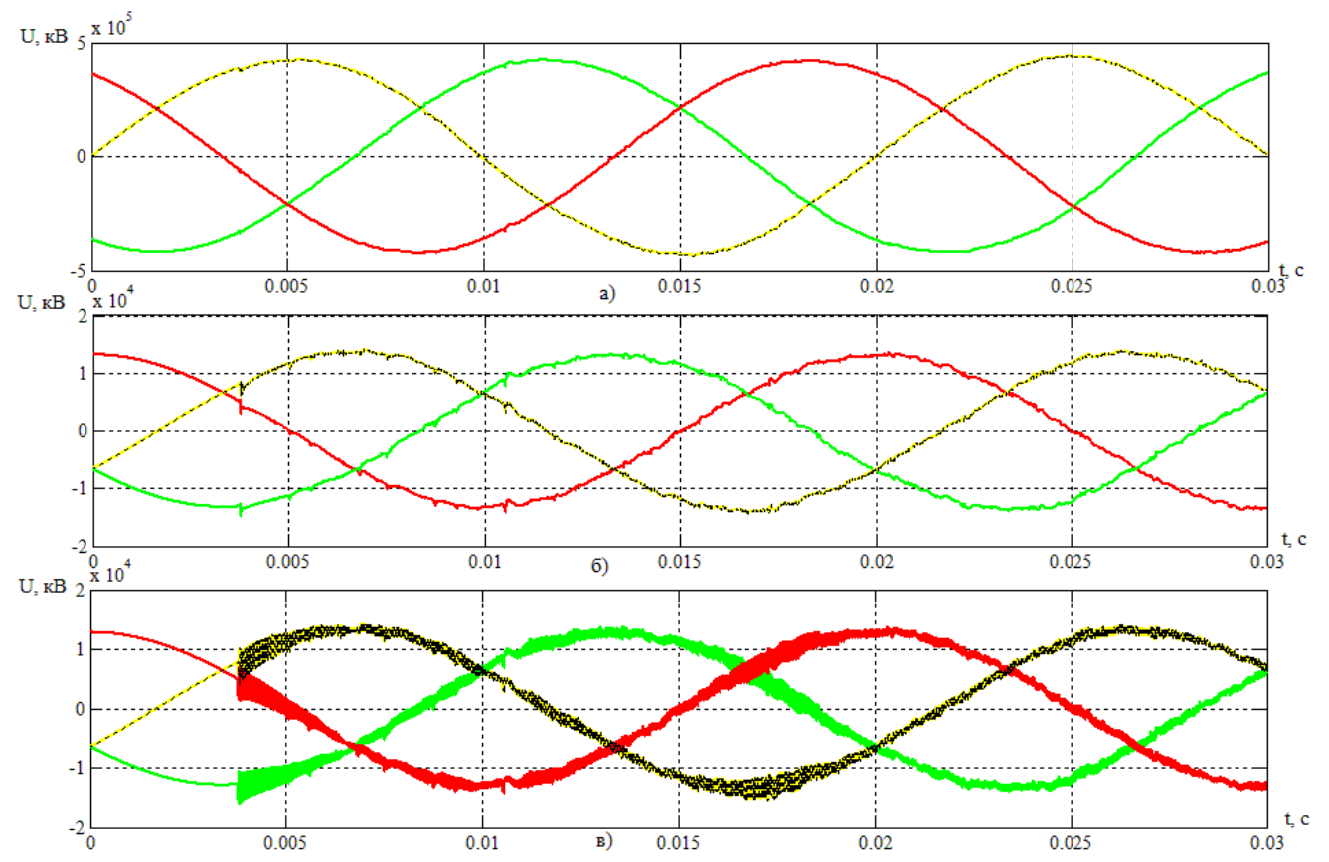

Fig. 6. Oscillations, considering all powerlines and autotransformer 1AT: a) on the part of $500 \mathrm{kV} 2 \mathrm{AT}$; b) on the part of $15 \mathrm{kV} 2 \mathrm{AT}$; c) at the transformer 4TSN

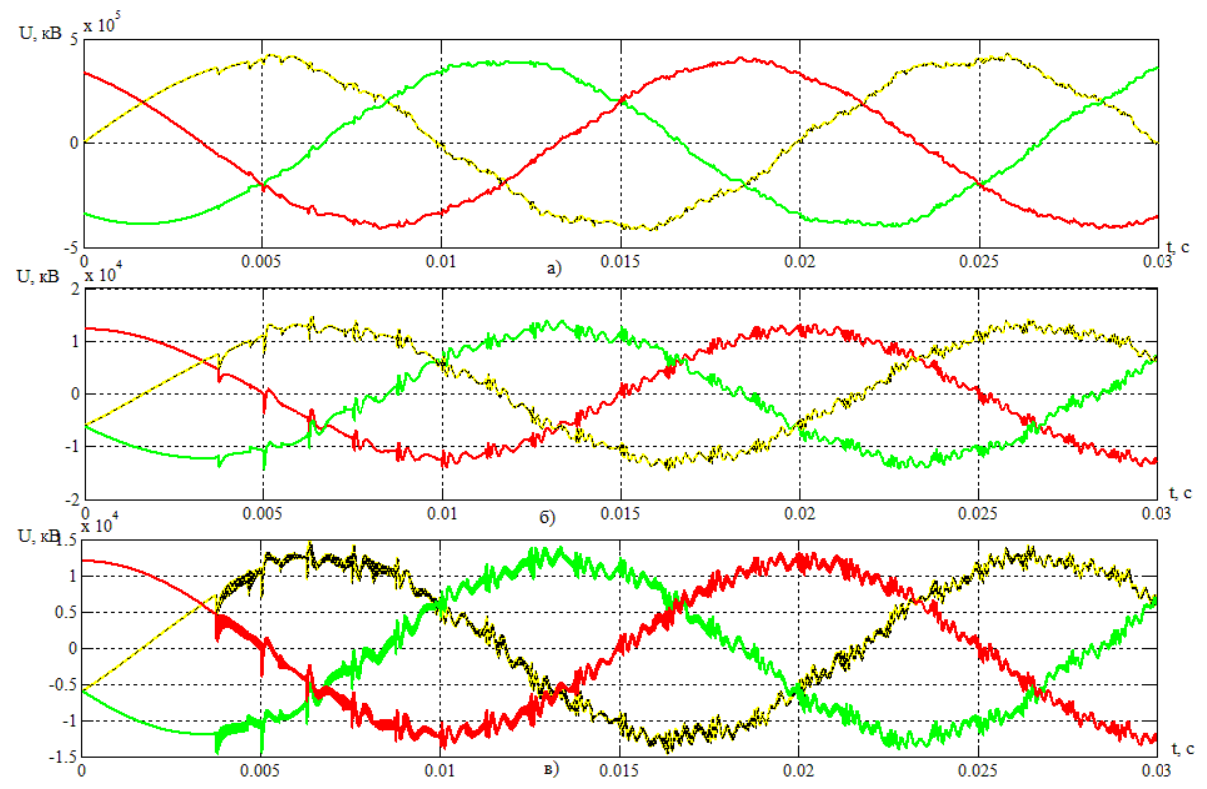

Fig. 7. Oscillations, with Zarya - Barabinskaya and Zarya - Altay disconnected: a) on the part of $500 \mathrm{kV} 2 \mathrm{AT}$; b) on the part of $15 \mathrm{kV} 2 \mathrm{AT}$; c) at tramsformer $4 \mathrm{TSN}$ 

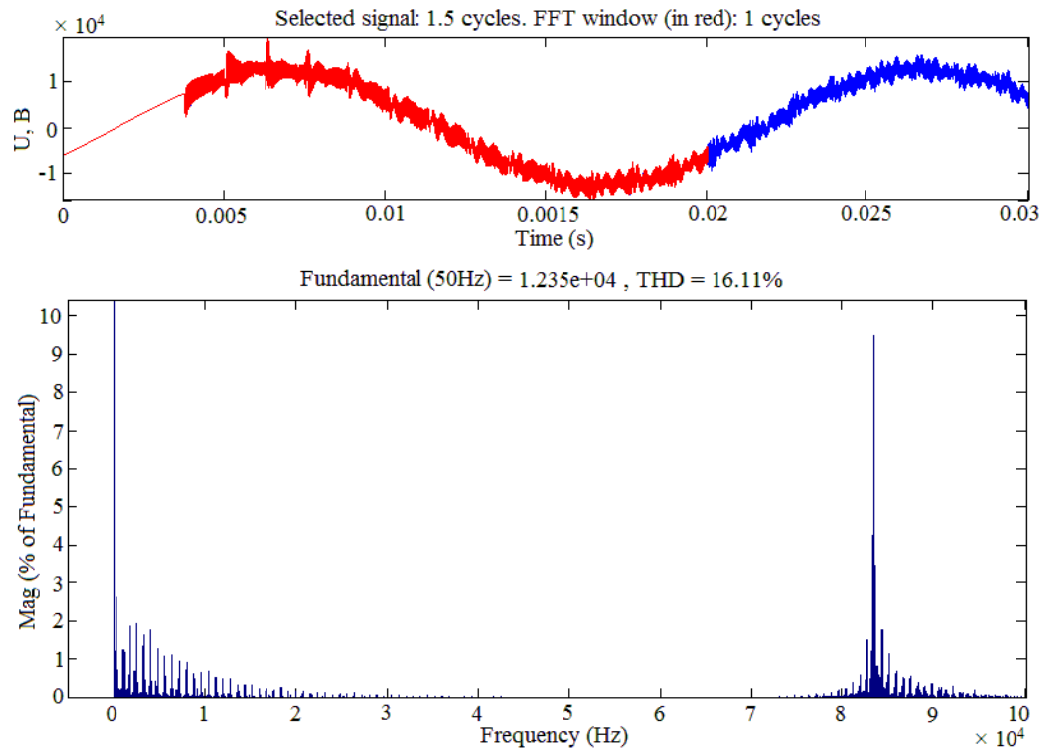

Fig. 8. Amplitude-frequency characteristic of oscillations of the phase A of 4TSN transformer

At the oscillogram of transient at OS $-500 \mathrm{kV}$ and transformer 4TSN, caused by the replicate sample of contact gap in a moment of TRV maximum on a breaker that disconnects SR (Fig. 9), it can be seen that at all the phases of a reactor intensive high frequency processes excite and that their multiplicity does not exceed 2.6 Uф макс due to the work of SA-15 kV. At the same time amplitudes of current through SA-15-4TSN do not exceed 12 A.

Calculated by fast Fourier transform, AFC of voltage at the transformer 4TSN (Fig. 10) reveales that apart from the frequency of $83,4 \mathrm{kHz}$ overvoltages include frequencies higher than $160 \mathrm{kHz}$.

It is necessary to be aware of resonant frequencies and parameters of resonance circuit of transformers winding in order to estimate the riskiness of different frequencies. Lack of these data prevents us from making an univocal conclusion about how much overvoltages with such frequency affect the insulation of transformer 4TSN's winding. Considered conditions are specific because of the fact that the transformer 4TSN TSZ-630/15-UHL3 possesses air insulation. In case of rigid and air insulations are combined, distribution of electrostatic field intensity is inversely proportional to dielectric permittivity of air and solid dielectric. Thus, electrostatic field intensity in winding air gabs is several times higher than in rigid insulation. Besides, as the frequency of applied voltage increases over $50 \mathrm{~Hz}$, electric rigity of air decreases significantly with the minimum of breakdown voltage when frequency is about $1 \mathrm{MHz}[4,5,6]$. While modeling the discharge voltages of air gaps with in homogeneous field, mentioned in [6], dependable of applied voltage frequency were used.

If take a average size of air gaps $15 \mathrm{kV}$ as $25 \mathrm{sm}$ (which is a building height of post insulations), the effective value of discharge voltage of approximately $55 \mathrm{kV}$ corresponds to the obtained value of overvoltage frequency which is $83,4 \mathrm{kHz}$. Thus, decrease of discharge voltage for air gaps with inhomogeneous field here with frequencies considered may exceed its double value.

According to [1] acceptable ration of overvoltages within an insulation of electric equipment $15 \mathrm{kV}$ and maximum operational phase voltage can be calculated using the following expression: 

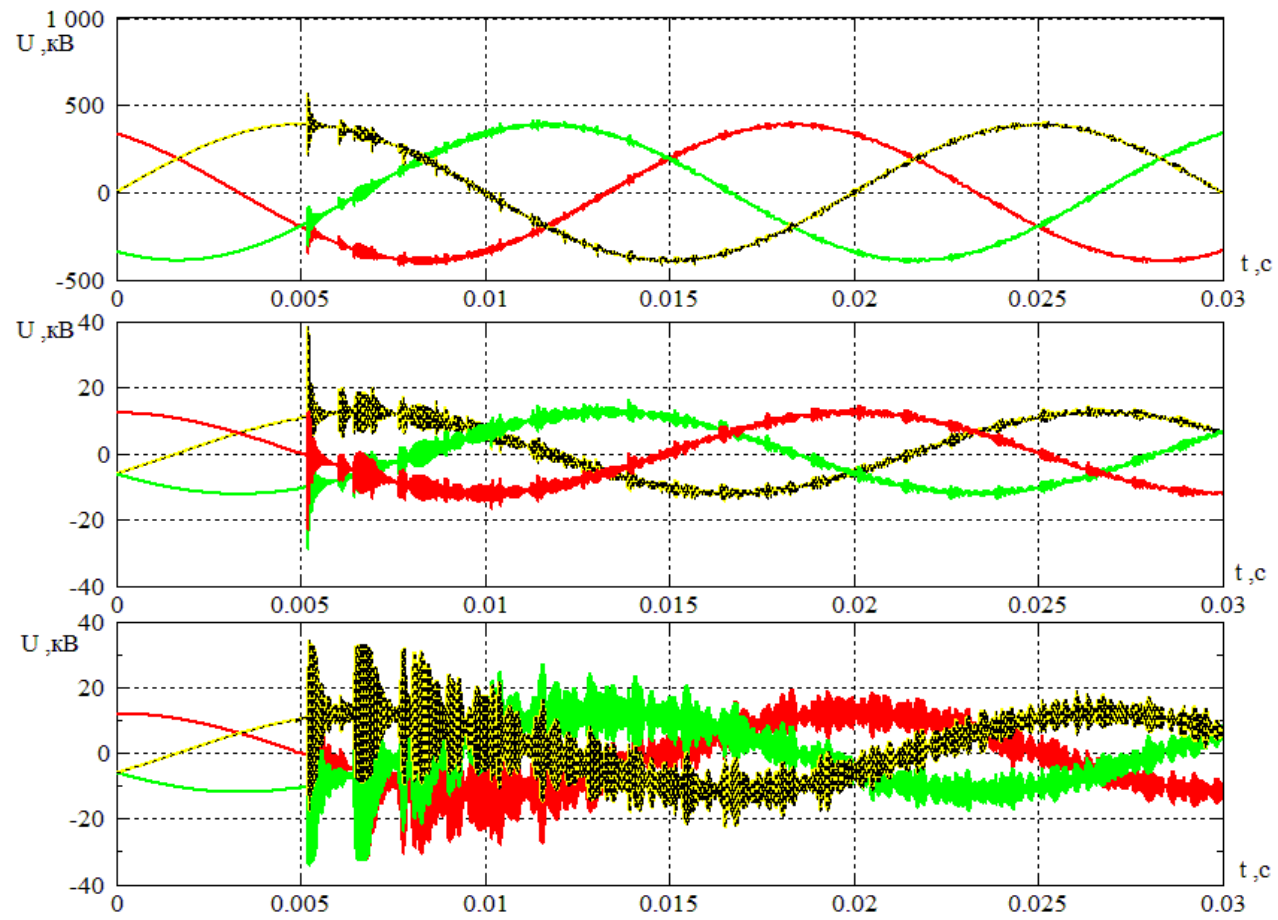

Fig. 9. Oscillations, caused by replicate sample in a breaker: a) on the part of $500 \mathrm{kV} 2 \mathrm{AT}$; b) on the part of $15 \mathrm{kV}$ 2AT; c) at tramsformer 4TSN
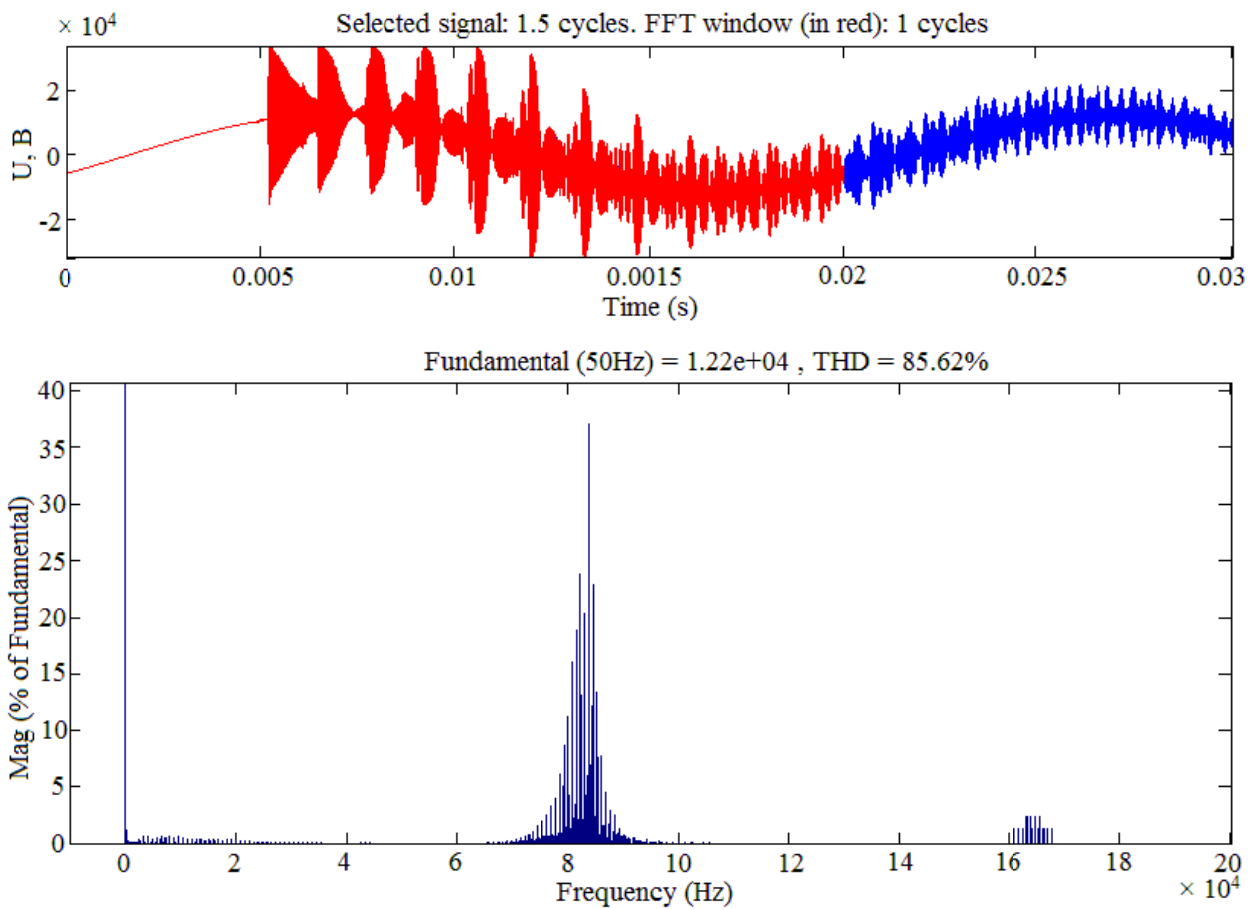

Fig. 10. Amplitude-frequency characteristic of oscillations of the phase A of 4TSN transformer 


$$
\mathrm{k}_{\text {доп }}=\mathrm{U}_{\text {доп }} / \mathrm{U}_{\text {нр }} \cdot \sqrt{3}=\mathrm{k}_{\text {и }} \cdot \mathrm{k}_{\mathrm{\kappa}} \cdot \mathrm{U}_{\text {исп }} / \mathrm{U}_{\text {нр }} \cdot \sqrt{3}=1.3 \cdot 0.9 \cdot 37 / 17.5 \cdot \sqrt{3}=4.3
$$

where $U_{\text {исл }}=37 \mathrm{kV}$ is a normalized one-minute factory test voltage (an effective value) of the major insulation at transformer TSZ-630/15; $k_{\mathrm{u}}=1.3$ is impulse coefficient herewith overvoltage within the major insulation of transformer is $6-35 \mathrm{kV}[1] ; k_{\mathrm{K}}=0.9$ is the cumulative coefficient [1].

The expression (2) does not consider presence of air gaps and considerable decrease of breakdown voltage herewith high voltage frequency in trancformer's insulation. Consideration of this decrease may demand for impulse coefficient kи [1] to be changed or replaced with descending coefficient while calculating acceptable internal overvoltages' multiplicity herewith high frequency effects, therefore if appears impossible to assess precisely the safety margin of an air transformer during high-frequency overvoltage using a norm coefficient $\mathrm{k}_{\text {доп }}$.

However, the suppositional double decrease in strength of insulation's air gaps of TSN-630/15 herewith high-frequency effects allows to conclude that despite the 4TSN was protected with surge arrestors, the effect of voltage with frequency of $83,4 \mathrm{kHz}$ and duration, longer than one of a switching impulse, can be harmful for air insulation of a transformer TSZ-630/15

It may be suggested to connect an additional capacity to terminals of a transformer 4TSN in order to reduce the high-frequency effects on 4TSN, caused by transformation of switching surge on the part of OS-500 kV. According to the calculations, it is possible to reduce high-frequency effects on transformer's insulation.

Investigation and analysis of high-frequency transients affecting the insulation of auxiliary transformer herewith commutations of a shunt reactor $500 \mathrm{kV}$ allows to make the following conclusions:

1. A disconnection of R-532 with current cutoff in a breaker isn't insecure for insulation of equipment on the part of a shunt reactor because multiplicities of overvoltages $1,8 \cdot U \phi$ макс do not exceed a normal GOST value $(2.5 \cdot U \phi м а к c)$ acceptable for insulation $500 \mathrm{kV}$ due to functioning of SA;

2. Transformation of transients with commutation of R-532 and OS-500 kV through $2 \mathrm{AT}$ into the AN $15 \mathrm{kV}$ causes significant high-frequency overvoltages at 4TSN. However the ratio of both transients to the ground and of transient to the interphase voltage do not exceed 2.6 Uф макс due to functioning of SA-15-4TSN;

3. Considerable number of high-frequency overvolages of $83,4 \mathrm{kHz}$ substantially is down to the excition of an oscillatory circuit, derived from the inductivity of a current-limiting reactor RB15-4TSN and the capacity of the transformer 4TSN;

4. Due to significant decrease of air gaps dielectric strength with high frequency $(83,4$ $\mathrm{kHz}$ ) and despite of formally low overvoltage multiplicities, the overvoltages at 4TSN with commutation of R-532 may be harmful for phase and interphase insulation of an air transformer TSZ-630/15;

5. A probable reason for failure of transformers SN TSZ 630/15 is decrease of dielectric strength of air insulation as overvoltage with frequency of $83,4 \mathrm{kHz}$ occurs;

6. To eliminate the high-frequency overvoltages and limit the multiplicity to $1.2 U \phi м л а к c$, so as to prevent failures at TSZ-630/15, it is necessary to install with capacity of 30-200 nF between the 4TSN transformer and the current-limiting reactor RB-15-4TSN the same as the analogous condensers 
K-15-1AT were installed between the current-limiting reactor and STK-1 within the circuit $15 \mathrm{kV}$ of the 1AT transformer

\section{References}

[1] РД 153-34.3-47.501-2001. Рекомендации по эксплуатации выбору выключателей, работающих в иепи шунтирующих реакторов. Введ. 01.09.2001. М.: РАО «ЕЭС России», АО «ВНИИЭ», 2001, 20 с. [RD 153-34.3-47.501-2001. Recommendations on use of the selection switches operating in the circuit of shunt reactors Recommendations on use of the selection switches operating in the circuit of shunt reactors. Moscow, RAO "EES Rossii", AO "VNIIE", 2001, 20 c. (in Russian)]

[2] Базавлук А.А., Кадомская К.П., Лавров Ю.А. Электро, 2009, 6, 31-34 [Bazavluk A.А., Kadomskaia K.P., Lavrov Iu.A. Elektro, 2009, 6, 31-34(in Russian)]

[3] Руководство по защите электрических сетей 6-1150 кB от грозовых и внутренних перенапряжений (рд 153-34.3-35.125-99) / под ред. Н. Н. Тиходеева. Изд. 2-е. СПб.: ПЭИПК Минтопэнерго РФ, 1999, 353 с. [Guidelines for the protection of electrical networks 6-1150 kV against lightning and internal overvoltages (rd 153-34.3-35.125-99). Ed. by N.N.Tikhodeev. Iss. 2. St. Petersburg, 1999, 353 p. (in Russian)]

[4] Than Duy Chu. High Frequency Breakdown Voltage, U.S. Department of Energy under, Superconducting Super Colluder Laboratory, 2550 Beckleymeade Ave. Dallas, 1992.

[5] Бабиков М.А., Комаров Н.С., Сергеев А.С. Техника высоких напряжений. M.: Госэнергоиздат, 1955, 287 c. [Babikov M.A., Komarov N.S., Sergeev A.S. High voltage equipment, Moscow, Gosenergoizdat, 1955, 287 p. (in Russian)]

[6] Техника высоких напряжений / под общ. ред. Д. В. Разевига. Изд. 2-е, перераб. и доп. М.: Энергия, 1976, 488 с. [High voltage equipment. Ed. by D.V.Razeviga. Iss. 2. Moscow, Energiia, 1976, 488 p. (in Russian)]

[7] Sizganov N.V., Sizganova E.U., Petrtliov R.A. Global Science and Innovation. Materials of the III International Scientific Conference, October 23-24m, 2014, Chicago, 2014, p. 369-374. 